\title{
THE IMPORTANCE OF SOCIAL INNOVATIONS IN RURAL AREAS
}

\section{A TÁRSADALMI INNOVÁCIÓK JELENTŐSÉGE A VIDÉKI PERIFÉRIÁKON}

\author{
Katalin LIPTÁK $K^{\mathrm{a}}$ \\ a University of Miskolc, Faculty of Economics, liptak.katalin@uni-miskolc.hu
}

Cite this article: Lipták, K. (2019). The importance of social innovations in rural areas. Deturope, 11(3), 160174.

\begin{abstract}
The aim of this study to analyze the difference between the classic sense of mechanical-technical innovation and the social innovation, as well as the analysis of the impact of social innovations on employmentenhancing and the role of it in the rural development. I have analysed the literature of the rural development and social innovation. The definition of social innovation in the literature is not yet uniform at the same time all, novel and innovative idea to overcome existing social problems can be considered as social innovation. The successful examples of social innovations play a key role; these can be observed in the local development or in the rural development. Those development strategies based on the participation of the rural society's members can be successful, which expect themselves as an innovation, and they suppose the renewal of the society. I have collected such social innovations (Hernádszentandrás - innovative public employment program involving the Romanises, Belecska - social land program, Nemesvámos - innovative manager approach and Poroszló - innovative tourism development) that have been developed in recent years either to develop underdeveloped areas or to catch-up deprived marginalized social groups and I have analysed these innovations and made some comparisons. As a result, the social innovations are playing an increasingly important role in rural development, as for the termination of the existing problems and it is also necessary the active involvement of the citizens and civil organizations. To do this, we need a local society that supports the local identity, the cohesion and the willing to do it locally.
\end{abstract}

Keywords: rural area, social innovation, employment expansion

\begin{abstract}
Absztrakt
A klasszikus értelemben vett müszaki-technikai innováció és a társadalmi innováció közötti eltérést, valamint a társadalmi innovációk foglalkoztatás bővítő hatásának elemzését és a vidékfejlesztésben betöltött szerepét tüzte ki célul a tanulmány. A társadalmi innováció definiálása a szakirodalomban még nem egységes ugyanakkor minden, a fennálló társadalmi problémák leküzdését szolgáló újszerü, innovatív ötlet társadalmi innovációnak tekinthetö. Olyan társadalmi innovációkat gyüjtöttünk össze, amelyek vagy elmaradott térségek fejlesztésére vagy hátrányos helyzetü marginális társadalmi csoportok felzárkóztatására születtek az elmúlt években. A társadalmi innovációk sikeres példáinak kiemelt szerepe jut, ezek megfigyelhetőek a helyi fejlesztésben vagy a vidékfejlesztésben is. A vidéki társadalom tagjainak részvételére alapozott azon fejlesztési stratégiák lehetnek sikeresek, melyek maguk is innovációnak számítanak, illetve a társadalom megújulását feltételezik. Úgy véljük, hogy a társadalmi innovációknak egyre nagyobb szerep jut a vidékfejlesztésben, hiszen a fennálló problémák megszüntetésére a müszaki és technikai innovációk már nem elégségesek és szükséges az állampolgárok, a civil szervezetek aktív szerepvállalása is. Ehhez pedig a helyi identitást támogató, a kohéziót és a helyben való tenni akarást segítő helyi társadalomra van szükség.
\end{abstract}

Kulcsszavak: vidék, társadalmi innováció, foglalkoztatás bővítés 


\section{INTRODUCTION}

The definition of social innovation in the literature is not yet uniform at the same time all, novel and innovative idea to overcome existing social problems can be considered as social innovation. The successful examples of social innovations play a key role by rural areas. These can be observed in both local development and in rural development. Those development strategies based on the participation of the rural society's members can be successful, which expect themselves as an innovation, and they suppose the renewal of the society (NemesFazekas, 2006). In this study, we present Hungarian social innovations, that were completed in rural areas and have also had an increasing effect, such as an additional profit.

\section{DIFFERENT APPROACHES OF THE SOCIAL INNOVATIONS}

The theoretical bases of the innovation first appeared in Schumpeter's study in 1934, describing five basic cases of innovations: selling new goods or the novel production of old goods, the introduction of new transportation methods; exploring new markets, the use of new production materials and the development of new market conditions (Schumpeter, 1980). Schumpeter meant professional development by the innovation. According to the Schumpeter innovation model, the companies implement innovation-based technological developments and consider them as the most important source of the economic growth. The competitive advantage of the advanced economies depends on the knowledge and the technological development, and knowledge is considered the basis of innovation in every case. The widespread dissemination of knowledge-based activities plays an increasingly important role in the competitiveness of each county and region. Knowledge - as an integral part of innovation - is part of that process that leads to innovation, and contributes to the increase of in prosperity and competitiveness (Schumpeter, 1980).

According to Rechnitzer (1998:32) an innovation milieu can be seen as a group of economic and production contacts that can be recognized in a given geographical area that create coherence in the production system between the economic characters and in the production cultures. It is possible to contribute to the dissemination of innovation processes with collective learning. The development of innovation milieu is geographically bound, as the innovation activity will be significant where the human capital and the collective knowledge are present in a given area. The classic Schumpeter innovation does not provide a sufficient solution to the problems of the rural society, as it has mainly focused on technical innovations and 
improvements, so an expanded view needs to be considered. A review of the different definitions of the social innovations follows.

The definition of social innovation in the literature is not uniform (Benedek et al., 2015; Benedek et al., 2016; G.Fekete, 2015b; Kocziszky et al., 2015; Kocziszky et al., 2017; Varga, 2017) yet at the same time all novel and innovative ideas to overcome existing social problems can be considered as social innovation. The first literature appearance of the concept is related to the name of Drucker (1985), who emphasized the importance of social innovations in the 1980s. According to Ogburn the combination or modification of the available intangible (cultural) elements will help the establishment of new products (Ogburn 1957:168). According to Whyte, the social innovations are the latest solutions to solve human problems (Whyte 1982:2). Another approach is that the amount of new solutions that support goals also help to better manage the problems which are a result of the new organization forms, new regulations and new lifestyles (Zapf 1989:177). Nowadays Mulgan's definition is popular, social innovation refers to innovative activities and services that are motivated by the goal of meeting a social need and that are predominantly diffused through organizations whose primary purposes are social (Mulgan, 2006).

G.Fekete (2015a:282) believes that the social innovation may mean simultaneously the involvement of social resources in the function of the economy (which is a new thing compared to the previous ones) and the new innovative solutions which satisfy social claims; as well as the development and dissemination of organizations with primarily social goals. The latter practically includes the former one. According to today's interpretation, an innovation is social if it meets the following criteria: (1) it is guided by social value; (2) the idea comes at least from the civil society, social movements; (3) new social cooperation or new forms are used in their development and implementation; (4) the impact on society.

The social innovation starts a process that leads to an improving quality of life and a more favourable economic and social situation for both the centre and periphery. Kocziszky et al., (2017:16) state that social innovation provides new or novel answers to a community's problem with the aim of increasing the community's well-being. Varga (2017:614) believes that social innovation brings new answers to the everyday problems of the given community in order to improve the community's well-being, and as a responsive tool to the challenges, it also leads to a novel approach in the treatment of the regional disproportions. In the core areas, the technical innovations provide a solution in the development questions of the quality of life, but as the peripheral areas are lagging behind it is necessary to take into account such new innovations, as social innovations. At the same time I do not agree with Varga's statements because the 
social innovations play a considerable role in the development of quality of life, not only in the peripheral areas, but in the core areas as well. A good example of this is the scope of activities and the social aim of the foundations of Miskolc which will be presented in the later chapters of this study.

Figure 1 The relation system of social innovation

\begin{tabular}{|c|c|c|}
\hline $\begin{array}{c}\text { Forms: } \\
\text { product } \\
\text { technology } \\
\text { service } \\
\text { organization } \\
\text { marketing } \\
\text { institutional system }\end{array}$ & & $\begin{array}{c}\text { Aims: } \\
\text { improving the quality of life } \\
\text { increasing the level of employment } \\
\text { public safety } \\
\text { improving the environmental } \\
\text { condition }\end{array}$ \\
\hline . & Social innovation & $\begin{array}{c}\text { Levels: } \\
\text { micro } \\
\text { mezo } \\
\text { macro } \\
\text { global }\end{array}$ \\
\hline $\begin{array}{c}\text { Innovators: } \\
\text { local and state government } \\
\mathrm{K}+\mathrm{F}+1 \text { sector } \\
\text { business sector } \\
\text { corporate enterprise } \\
\text { NGOs (networks) } \\
\text { households }\end{array}$ & & $\begin{array}{l}\text { Financing: } \\
\text { self-financing } \\
\text { public funds } \\
\text { EU funds }\end{array}$ \\
\hline
\end{tabular}

Source: Kocziszky - Veresné - Balaton (2017:16)

The social innovation may contribute to the improvement of the quality of life of people living in peripheral or rural areas and may help to catch up in social and economic terms. Figure 1. illustrates the close relationship between the social and the science innovations. On this basis, it can be stated that there is a close relationship between social innovation and economic development. Nowadays, the importance of social innovation is not less than the technical or economic innovation, and the social problems caused by technical and economic innovations can be solved by innovation (Kocziszky et al., 2017).

According to Caulier-Grice et al. (2012) there are five core elements of social innovation: (1) novelty, (2) from ideas to implementation (there is a distinction between invention and innovation), (3) meets a social need, (4) effectiveness and (5) enhance society's capacity to act.

According to Seelos and Mair (2017) the social innovation is not the Holy Grail, because of the overeating the value of innovation, the undervaluing the importance of failed innovation and the under appreciating the difficulty of innovation. They wrote that there are some difficulties (for example how to prevent people from going into too many new directions) and 
Lipták, K.

the process of the learning social innovations is very important. They argue that the purpose of innovation is the creation of social impact, and its success depends on three interlinked factors: understanding the societal problem or social need; internal capability; and a strong sense of mission and strategy.

\section{THE "PROBLEMS" OF THE RURAL AREAS AND THE RURAL DEVELOPMENT}

The concept of the rural areas and the countryside itself has undergone a major transformation in Hungary in the last decades. In the European Union, there is no definition of the same rural concept for all member states (Vincze, 2013). The three dimensions of rurality are described by Káposzta - Nagy (2013). These are the occupational, sociocultural and ecological dimensions. In terms of employment, rurality is the synonym of agriculture (or other raw material production). In a sociocultural sense, it means such a lifestyle forms the basis of different values, behavioural patterns and social attitudes from the urban ones. Ecological rurality is the recognition of the importance of the natural environment from the qualitative aspects of the human's social life (Káposzta - Nagy, 2013:73). I think that currently the occupational dimension is no longer applicable because the rural area cannot be fully identified with agriculture. As there are several different approaches to the concept of the rural areas, different approaches are also known to the concept of the rural development. According to Vincze (2013), rural development means self-sustaining and sustainable development of the capacities of rural area. I believe that the self-sustainers should not be used here literally, but rather less strong dependence on the centre regions and their markets.

Endogenous rural development builds on local natural and social resources as well as onto the local culture or identity. Because of the peculiarities of development in peripheral and rural areas, the appearance and the trips of the innovations are different as in the centre regions. The composition of the society in the peripheral region and its different use of space, as well as its relation to the culture and customs, require a different path. It is needed deeper acceptance of the new solutions and innovations; it takes more time. Foreign and domestic good practices highlight that in the rural and peripheral innovation:

- there is no recipe, every solution proved to be successful is unique;

- new products and procedures are created in practice, not in scientific workshops;

- social innovations are as important as the mechanical-technical innovations;

- the spread of the innovations takes place through horizontal (non-hierarchical) relationships (G. Fekete, 2016). 
Tab. 1 summarizes the special social purpose and task that can be assigned to the specificities of rural areas.

Table 1 Potential areas of social innovation in rural areas

\begin{tabular}{|c|c|c|}
\hline rural pecularity & social purpose & special task \\
\hline $\begin{array}{l}\text { low population } \\
\text { concentration }\end{array}$ & $\begin{array}{l}\text { reducing deprivation/ making } \\
\text { services available } \\
\text { territorial and social integration, } \\
\text { inclusion }\end{array}$ & $\begin{array}{l}\text { introduction of alternative (small-scale) } \\
\text { service mode: education, culture, health, } \\
\text { social care, communal services } \\
\text { organizing cooperation and integration, } \\
\text { building internal networks, improving } \\
\text { horizontal transport }\end{array}$ \\
\hline contact with nature & $\begin{array}{l}\begin{array}{l}\text { to provide a healthy living } \\
\text { environment for } \\
\text { generations }\end{array} \\
\text { future }\end{array}$ & $\begin{array}{l}\text { the creation of the conditions of of } \\
\text { environmental sustainability: nature } \\
\text { protection, landscape maintenance, use of } \\
\text { alternative energy sources, waste } \\
\text { management, home renovation, settlement } \\
\text { maintenance } \\
\text { utilizing local (natural and cultural) } \\
\text { resources: regional food production, } \\
\text { expanding recreational opportunities, } \\
\text { offering residential properties }\end{array}$ \\
\hline $\begin{array}{l}\text { slower cultural } \\
\text { changes }\end{array}$ & $\begin{array}{l}\text { the promotion of school } \\
\text { inclusion, enabling innovations, } \\
\text { preservation of identity, } \\
\text { achieving direct participation, } \\
\text { capacity enhancement }\end{array}$ & $\begin{array}{l}\text { expansion of knowledge: local knowledge, } \\
\text { expertise, development of digital literacy } \\
\text { (trainings), preservation of cultural } \\
\text { heritage, traditions, community } \\
\text { strengthening }\end{array}$ \\
\hline $\begin{array}{l}\text { geographical } \\
\text { distance from the } \\
\text { centres }\end{array}$ & achievement of markets & $\begin{array}{l}\text { development of network connections: help } \\
\text { commuting, the achievement of markets } \\
\text { and its organization, (physical, } \\
\text { informational, social) networks building, } \\
\text { presence and representation in the urban } \\
\text { and regional opinion formation and } \\
\text { decision-making }\end{array}$ \\
\hline
\end{tabular}

Source: own editing, based on G. Fekete (2016:82)

As a result of low concentration of the services that are available, tasks can be assigned to introduce alternative services. The natural proximity can be an advantage in the peripheral areas if healthy living and livelihoods can be provided for future generations. Building upon local resources will ensure environmental sustainability and strengthening of the local economy. Slower cultural changes also strengthen the local community to the easier reception of the social innovations, resulting from the preservation of the local knowledge, old values and traditions. The local knowledge is an important endogenous resource for the country and the preservation and the enhancement of the local culture (Kulcsár, 2017) and the diversity of members of the local society. In the case of distance from the centres the social goal is to reach the urban markets, thus strengthening the urban-rural relations. 
The members of rural society increasingly need to apply novel solutions to alleviate the unfavourable economic and social processes. The main problem is the rural society's considerable decline in population, which can be identified by the challenges of a declining and aging society typical of the European Union as a whole, as well as by the migration processes (the strong inner migration also increases the adverse situation in the case of Hungary). The demographic composition of rural areas provides information on the human resources base, which also indicates the state of the labour market. Rural areas are characterized by a low number of workplaces and the lack of service sectors, leading to a decline in the population of rural society (Koncz et al., 2015). Significant income disparities and the Hungarian regional disparities further exacerbate the 'unfavourable' rural image (Szendi, 2017). In the disadvantaged rural areas, a fundamental problem is that minimum private capital can be mobilized so development is largely realized from public funds (Koncz et al., 2015). At the same time, it is unfortunate that significant costs can have a relatively small impact on development, which increases territorial differences (Finta, 2015).

Bell and Jayne (2010) deals with the creative countryside in the United Kingdom. They argue the need to consider 'the countryside' as a place where the creative economy is differently manifested and articulated from the now standard 'creative script' based on cities.

Social innovation can be one of the devices of the rural development as Szörényiné 82015:205) composes: the social innovation is an inevitable element of rural development. However, it is a basic condition that the rural areas be viable with an active community, strong economy and a good public utility service. Five basic principles of the rural development have been defined. These include innovation, sustainability, competitive rural space, acceptance and establishment of knowledge-based rural society and the need for new functions (Szörényiné, 2015). One of the most well-known examples of social innovations in the rural areas is the establishment of the network of village caretakers, as well as micro-regional organizations created as a bottom-up initiative. According to G. Fekete (2016) the rural area can be considered a spatial loser of modernization of the rural population and the deteriorating indicators of living conditions.

Nowadays, the concept of wage labour in the previous sense cannot succeed. It needs a new interpretation and has to be given a value-creating, social organizing function with new goals and new contents that are much more present in rural areas (Rimler, 1999; Vobruba, 2000; Csoba, 2006; G.Fekete, 2015a) Therefore, in the post-industrial society, the employment model is based on the concept of changed work and shows a shift towards a mixed economy and a solidarity economy. We would like to deal with the labour-market issues by examining the 
problems and challenges of society because most social innovations are trying to solve the existing employment problems, but they are not enough in themselves. Work was interpreted as the means of achieving wealth, while unemployment was interpreted as the misfortune of the society.

\section{SOME GOOD EXAMPLES OF HUNGARIAN SOCIAL INNOVATION}

We have collected such social innovations that have been developed in recent years either to develop underdeveloped areas or to catch-up deprived marginalized social groups. On this point, we observe that the range of social innovations is much broader, and the examples presented by us are truly exemplary. Special caution should be exercised, because it more often occurs recently that we call something as a social innovation which is in fact not.

Table 2 Some good examples of social innovation

\begin{tabular}{|l|l|l|}
\hline \multicolumn{1}{|c|}{ Type of social innovation } & \multicolumn{1}{c|}{ Settlement } & \multicolumn{1}{c|}{ Primary aim } \\
\hline $\begin{array}{l}\text { innovative public employment } \\
\text { program involving the Romanises }\end{array}$ & Hernádszentandrás & $\begin{array}{l}\text { increase employment, rural } \\
\text { development }\end{array}$ \\
\hline $\begin{array}{l}\text { social land program, social } \\
\text { employment program }\end{array}$ & Belecska & local economic development \\
\hline innovative manager approach & Nemesvámos & local economic development \\
\hline innovative tourism development & Poroszló & tourism development \\
\hline
\end{tabular}

Source: own editing

\section{Innovative public employment program involving Romany in Hernádszentandrás}

Hernádszentandrás is famous about the the public employment program, the village is located in the North Hungarian region. The production and sales of vegetables is under the brand name of Bioszentandrás. They have been engaged in organic farming for many years, which further increases the market value of the produced raw materials. It provides a job opportunity for 2530 people (Katonáné et al., 2017). It is important to emphasize that for the low-status population, public work is not in the wrong place in the hierarchy of available jobs (Kovai, 2016). The social innovation is often appointed as an essential part of agricultural and rural innovation (Bock, 2012), which are characterised by co-production of economic and social values or benefits. The social innovation here lies not only in the production of vegetables, but in that social process which takes place through the involvement of civil society characters. We regard it as a social innovation because the land and the workforce were available to create a new farming model, but the knowledge, resources and the contacts were missing. These were supported and generated by the "local hero", the mayor's deputy, and to the targeted actions related to his person itself and his ideas. Furthermore, it can be considered as an innovative 
solution because it also includes the idea of social responsibility, as it rejects the processes that focus on profit maximization. Learning is a feature of social innovation. It is a process that can be detected by the change management understanding of the problem (Nemes \& Varga, 2015). Thus, social learning can be defined as a kind of capacity that enables the community to do such an activity what it would not have been able to do before. (www.bioszentandras.hu)

\section{Social land program in Belecska}

Belecska is a village with 365 inhabitants in the Tamási district in Tolna County, it was launched a social land program. After the change of regime, the inhabitants of the settlement became unemployed by the dissolution of the TSZ cooperative (Petrovicsné, 2006). The fundamental purpose of the social land program is to eliminate the symptoms of the crisis (Keller et al., 2016). The mayor definitely wanted to make it possible for families with small children to have a job locally, because he was afraid of a mass migration. He offered job instead of the social aid for the unemployed people (Keller et al., 2016). The mayor's person is also vital at this social innovation, as he was the mastermind, and he kept the interests of the settlement in mind. For more than fifteen years, there has been a purely public employment program based on vegetable and fruit production. Within the framework of the social land program, vegetable and fruit production has started at the end of the '90s from a tender source; they dealt with strawberry growing initially. The strawberry brought in money well, which made it unambiguous that the Belecska vegetable and fruit-growing may have future. As a result, the program has been continuously expanded, which has continued steadily ever since. Production is currently taking place on 25 hectares: on the one hand, the government's own land is involved and on the other hand long-term rentals are also used. Monoculture cultivation based on only strawberries for a short time was soon expanded, which has led to the introduction of many vegetable, fruit and grape varieties; and growing and cultivating additional plants is included in the plans (Németh, 2011). According to Keller et al. (2016) this is a model program to promote the introduction of the social economy in Hungary.

The system working in Belecska is called a social land program in the press and in the general terms, in the traditional sense it is not a land-work program. The essence of the classic social land-works programs is that those who do not have the necessary resources for agricultural production, those who cannot operate it efficiently, and those who are socially disadvantaged, have the opportunity to provide small-scale housing and livestock farming with the utilisation of individual and community and local resources (Jász-Sarvák-Szoboszlai, 2003: 
139). The Belecska program rests on foundations differing from this ideal type. By placing the production and sales within the framework of a non-profit enterprise, the government has created a unique local employment solution that is inseparable from the land, but not a landwork program. It is more appropriate to call the Belek system as a social employment (social economy, community based economy, village economy) program based on the government's enterprise (Németh, 2011).

For the operation of the program, in 2002, because of the administrative problems and the VAT regulations, the Municipal Public Utility Company of the Government of Belecska, which is a sole proprietor of the government, was established. It was transformed into a non-profit Ltd. on 1 July 2009. The program gives job for the locals nowadays, as well. Belecska supplies itself from vegetables and fruit, and also produces for the regional market. As a result of the land-work program, the initial 30\% unemployment rate fell to a negligible level. The program has significantly reduced the uncertainty of life, it is a very important indirect result that children are born again in the settlement, population decline has stopped; it is essentially stagnant, and in some years the population is growing slightly. As a result of the program, social assistance ceased to exist, unemployment was virtually eliminated in the village, and all this was achieved through community management.

The Belecska case is instructive because most social innovations are not only successful in themselves, but there are also good examples of its adaptation. For social innovations, the practice of transplanting to other areas would be very important, as it is good practice. We can see that even in the settlements of the Tamási district, in the settlements similar to Belecska, it was not possible to take over this relatively simple social innovation. The spontaneous adaptation of the Belecskai program may be hindered by at least some of the essential elements of the program. However, the Belecskai case is not as clear to the other settlements, although the mayor has already introduced the key elements of community agriculture in several social forums, but the knowledge of it is little. Something else is needed for the adaptation, and this is the ambition for self-preservation, which was successfully implemented in Belecska. The other settlements with similar economic and social conditions in the Tamási district do not have land in the outskirts of the countryside, nor do they have any capital for buying or renting land. According to Németh (2011), there is no any special feature of Belecska behind the achievements of the rural economy program, that is, there are no local factors or resources that might be difficult or expensive to take over or reproduce to prevent other settlements from trying to solve their employment problems in this way. 
Lipták, K.

\section{Innovative management approach at Nemesvámos}

Nemesvámos is not far from the Lake Balaton with a population of 2500 people, based on the latest census data. After the change of the regime, not only the successful tenders had a big impact on the settlement, but the multinational companies' settlement also had an effect. Alcoa - Köfém Ltd. is based in Székesfehérvár and one of its sites can be found on Nemesvámos. It currently employs 1700 people, of whom 120 employees work at the Nemesvámos site. In August 2000, the HARIBO factory was built in a green zone on 23,000 square metres. In 2006, the two-shift work schedule was expanded to three shifts, with a workforce of 160 people. In almost four years, the factory increased production by six-fold, and the number of employees has tripled. Nemesvámos has attracted more and more businesses, thanks to its favourable business environment and local government regulations. For example, we can mention the free utilities transfer and the implementation of road constructions without contribution. Initially, the measure of the local trade tax was only one or two thousandths; however, over the years this has increased with the developmental rate of the enterprises.

In addition to increasing local economic development, Nemesvámos also played a important role in community development. During this time, local authorities emphasized that, among other things, such implementations will be accomplished without contributions from residents. As a result, the households can keep or even increase their savings, so local incomes can be spent locally. In 2010, a new mayor was elected in the settlement. The biggest change was caused by the fact that the new mayor started his work with a management approach. He considered Nemesvámos an enterprise. Continuing the previous work, new ideas were formulated resulting in the establishment and the maintenance of financial independence for the village. Furthermore, the creation and the retention of independent decision-making possibilities were critical. As a result of the needs of the residents, local products have emerged, creating a local market. The employment has started to grow due to the more than 260 undertakings. (http://www.nemesvamos.hu/)

\section{Innovative tourism development in Poroszló}

Poroszló is a village of 2900 inhabitants in the country of Heves, which is known for its ecological centre of Lake Tisza. In the years following the change of regime, the settlement was not able to exploit its existing natural resources yet. In 1995, thanks to the leader of the settlement at the time, a change of attitude and tourism development occurred. Several services are now available in the settlement, such as equine tourism, community spaces and fishing 
opportunities. One of the most loved and most visited locations is the Ökocentrum. There are 11 civil society organizations, which are crucial for generating social innovations. Today, Poroszló has so many tourist attractions and opportunities connected to them that they have gained a reputation, not only for the area of the Lake Tisza, but also to the whole of Hungary. The Ökocentrum is made up of several diverse parts, which showcase the wildlife of Lake Tisza. In order to achieve such successful tourism results for the village, it was necessary not only to reinterpret and use the local sources. For the members fo the economic and tourism industry in the small town to work together (Kis \& Tóth, 2016).

Social innovation built on tourism also plays a role in increasing employment, which is a key feature in such a low-population settlement. Poroszló was able to see, realize and rethink its local conditions, and the possibilities that could be achieved in their community including providing space for the expansion of ecotourism and the initial quantitative and qualitative development of the enterprises based on it. In addition, the community played an outstanding role in collaborating and helping each other to promote these actions.

\section{CONCLUSION}

The local governments have an important role by the above illustrated social innovation examples, because they are the main actors. The aim of local governments was to mobilize local resources, involve stakeholders. The settlements receive normative support (for example for the public work program) from the Hungarian government. Pálné (2019) points out that although Hungarian local governments received considerable autonomy following the systemic change, they have gradually weakened and lost their significance and capacities ever since. Local governments lost most of their previous competences in public services. Not only did local governments lose their position as public authorities in Hungary, but partly as a result of these losses, their local relations systems do not promise to pursue an economic development strategy based on local resources and co-operation. In a previously fragile, in many ways asymmetric power structure, local governments were placed on the periphery, not only in the national but also in the local dimension of governance (Pálné, 2019). This is a major problem by the settlements and their social innovation.

The above described successful Hungarian social innovations are truly a model approach and had a positive effect on those settlements where they were implemented. I chose Hungarian examples of settlements that had similar characteristics. The social innovations and the rural developments are in close connection with each other. Innovative solutions to the earlier 
existing problems can be adapted to any other settlement, as in many cases it is necessary to strengthen the capacity of the population and a strong characteristic, "local hero", as well as the idea itself and the will. Most social innovations will be successful if the host environment and the inhabitants of the settlement are willing to take part in a development or at least not hinder its implementation. The process of social learning is also important to the acceptance of the social innovations. From the above mentioned example it can be seen that the civil people play a significant role in the solution of the existing social problems for rural areas, since these areas or socioeconomically disadvantaged labour-market groups themselves are not able to solve their problems.

For social innovation to be realized, it is necessary to have a local contact who is key to the implementation of ideas and who can work with local people beyond their direct environment and community. If its acceptance occurs relatively quickly, the spreading of innovation is fast, its impact is irreversible, and its sustainability is high. As a result, the social innovations are playing an increasingly important role in rural development, as for the termination of the existing problems and it is also necessary the active involvement of the citizens and civil organizations. To do this, we need a society that supports its local identity, the cohesion and the willingness to implement innovation locally.

\section{Acknowledgement}

This research is supported by project no. EFOP-3.6.2-16-2017-00007, titled Aspects on the development of a smart, sustainable and inclusive society: social, technological, innovation networks in employment and the digital economy. The project has been supported by the European Union, co-financed by the European Social Fund and the budget of Hungary.

\section{REFERENCES}

Bell, D., \& Jayne, M. (2010). The creative countryside: Policy and practice in the UK rural cultural economy. Journal of Rural Studies, 26(3), 209-218. https://doi.org/10.1016/j.jrurstud.2010.01.001

Benedek, J., Kocziszky, G., \& Veresné Somosi, M. (2015). Új innovációs paradigma? Regionális társadalmi innovációs potenciál javításának lehetősége szakértői rendszer segítségével, lehetőségek és korlátok. In: Veresné Somosi Mariann: „Mérleg és Kihívások” IX. Nemzetközi Tudományos Konferencia, Konferencia kiadvány

Benedek, J., Kocziszky, G., Veresné Somosi, M., \& Balaton. K. (2016). Generating and Measuring Regional Social Innovation. Theory Methodology Practice: Club of Economics in Miskolc, 12(special issue), 14-25.

Bock, B. (2012). Social Innovation and Sustainability; How to Disentangle the Buzzword and its Application in the Field of Agriculture and Rural Development. Studies in Agricultural Economics, 114(2), 57-63.

Caulier-Grice, J., Davies, A., Patrick, R., \& Norman, W. (2012). Defining Social Innovation. A deliverable of the project: "The Theoretical, Empirical and Policy Foundations for 
Building Social Innovation in Europe" (TEPSIE), European Commission - 7th Framework Programme, Brussels: European Commission, DG Research, 43.

Csoba, J. (2006). Foglalkoztatáspolitika. Debrecen: Debreceni Egyetem Szociológia és Szociálpolitika Tanszék

Drucker, P. (1985). Innovation and entrepreneurship. Harper \& Row, Publishers, New York

Európai Parlament, Foglalkoztatási és Szociális Bizottság (2011). A fogyatékossággal élö személyek mobilitásáról és befogadásáról, valamint a 2010-2020 közötti időszakra vonatkozó európai fogyatékosságügyi stratégiáról

Finta, I. (2015). Az integrált terület- és vidékfejlesztés eszközei és korlátai Magyarországon. Tér és Társadalom, 29(1), 132-148.

G. Fekete, É. (2015a). Társadalmi innovációk a helyi foglalkoztatásban. In: Veresné Somosi Mariann, Lipták Katalin (szerk.), „,Mérleg és Kihívások” IX. Nemzetközi Tudományos Konferencia, pp.274-287.

G. Fekete, É. (szerk.) (2015b). Társadalmi innovációk a felzárkóztatás szolgálatában: DélCserehát - Nyitás a jövöre. Miskolc: Miskolci Egyetem Gazdaságtudományi Kar

G. Fekete, É. (2016). Társadalmi innovációval a vidék fenntartható fejlődéséért In: Nagy Zoltán, Horváth Klaudia (szerk.) Jubileumi tanulmánykötet Tóthné Szita Klára professzor asszony 70. születésnapjára. Miskolc: Miskolci Egyetem Gazdaságtudományi Kar, 7488.

Jász, K., Szarvák, T., \& Szoboszlai, Zs. (2003). A szociális földprogram társadalomfejlesztési hatásai. Kállai E. (eds.): A magyarországi cigány népesség helyzete a 21. század elején. Kutatási gyorsjelentések. MTA Etnikai-nemzeti Kisebbségkutató Intézet, Budapest, pp. 139-145.

Káposzta, J., \& Nagy, H. (2013). Vidékfejlesztés és a környezetipar kapcsolatrendszere az endogén fejlödésben. Journal of Central European Green Innovation, 1(1), 71-82.

Katonáné Kovács, J., Varga, E., \& Nemes, G. (2017). Fókuszban a társadalmi innováció folyamata a magyar vidéken. Észak-magyarországi Stratégiai Füzetek, 14(1), 6-19.

Keller, J., Rácz, K. \& Váradi, M.M. (2016). Közösségi gazdaságfejlesztés a vidéki Magyarországon, In: Kovács, K. (ed.) Földböl élők. Polarizáció a magyar vidéken. Argumentum Kiadó, 197-217.

Kis, K., \& Tóth, A. (2016). Az ökoturizmus helyi rendszerének vizsgálata Poroszlón, különös tekintettel a Tisza-tavi Ökocentrum helyi gazdaságfejlesztési szerepének értékelésére. Észak-magyarországi Stratégiai Füzetek, 13(1), 73-91.

Kocziszky, G., Benedek, J., Veresné Somosi, M., \& Balaton, K. (2015). Regionális társadalmi innováció generálása szakértői rendszer segítségével. Észak-magyarországi Stratégiai Füzetek, 12(2), 4-22.

Kocziszky, G., Veresné Somosi, M., \& Balaton, K. (2017). A társadalmi innováció vizsgálatának tapasztalatai és fejlesztési lehetősége. Vezetéstudomány, 48(6-7), 5-19.

Koncz, G., Deme, P., \& Kerényi, G. (2015). Zöldenergia és a vidékfejlesztés kapcsolódásai. Journal of Central European Green Innovation, 3(special issue), 79-96.

Kovai, C. (2016). Önellátó függőség. In: Kovács, K. (ed.) Földből élők. Polarizáció a magyar vidéken. Argumentum Kiadó, 130-153.

Központi Statisztikai Hivatal (2014). Népszámlálás 2011.11. Fogyatékossággal élök. Budapest, $\mathrm{KSH}$

Mulgan, G. (2006). The Process of Social Innovation. Innovations: Technology, Governance, Globalization, 1(2), 145-162.

Nagy, Z. É., Pál, Zs., Szerepi, A., \& Halmai, R. (2008). A megváltozott munkaképességü és fogyatékossággal élö emberek társadalmi és jogi helyzete Magyarországon és nemzetközi kitekintésben. Helyzetfeltáró tanulmány. Budapest: Revita Alapítvány 
Nemes, G., \& Fazekas, Z. (2006). The road to a new European rural development paradigm. Studies in Agricultural Economics, 104(5), 5-18.

Németh, N. (2011). Helyi kezdeményezésü gazdaságfejlesztési programok vizsgálata, KTI könyvek 14., Budapest

Ogburn, W. F. (1957). Cultural Lag as Theory. Sociology and Social Research, 41(3),167-174.

Pálné Kovács, I. (2019). A magyar önkormányzatok korlátai a helyi gazdaságfejlesztésben. Tér és Társadalom. 33(2), 3-19.

Petrovicsné Takács, R. (2006). A belecskai modell. Nagyné Varga I., Landau E. (eds.): Szociális földprogram modellek. Jász-Nagykun-Szolnok Megye Esély Szociális Közalapítvány Regionális Szellemi Forrásközpont, Szolnok

Rechnitzer, J. (1998). Területi stratégiák. Budapest: Dialóg Campus Kiadó

Rimler, J. (1999). A munka jövője. Új fogalmak, feltételek, forgatókönyvek. Közgazdasági Szemle, 46(9), 772-788.

Seelos, C., \& Mair, J. (2017). Innovation and Scaling for Impact. How Effective Social Enterprise Do It. Stanford, California: Stanford University Press

Schumpeter, J. (1980). A gazdasági fejlődés elmélete: Vizsgálódás a vállakozói profitról, a tőkéről, a hitelről, a kamatról és a konjuktúraciklusról. Budapest: Közgazdasági és Jogi Könyvkiadó

Szendi, D. (2017). The Connection of EU Supports and the Taxable Income Per Capita in the Northern Hungarian Region, for the 2007-2013 Period. Deturope. 9(3), 42-60.

Szörényiné Kukorelli, I. (2015). Vidéki térségeink innovációt befogadó képessége - Egy kutatás tapasztalatai. Tér és Társadalom, 29(1), 97-115.

Varga, K. (2017). A regionális társadalmi innováció kérdései. International Journal of Engineering and Management Sciences, 2(4), 602-616.

Vincze, M. (2013). A vidékfejlesztés problémáinak rendszerszemléletü megközelítése. Romániai sajátosságok. Erdélyi Múzeum, 75(3), 30-51.

Vobruba, G. (2000). Alternativen zur Vollbeschäftigung Die Transformation von Arbeit und Einkommen. Frankfurt am Main: Suhrkamp

Whyte, W. (1982). Social inventions for Solving Human Problems. American Sociological Review, 47(1), 1-13.

Zapf, W. (1989). Über soziale Innovationen. Soziale Welt, 40(1-2), 170-183.

http://www.bioszentandras.hu/ letöltés ideje: 2018.02.14.

http://www.nemesvamos.hu/ letöltés ideje: 2018.03.13.

http://www.tiszataviokocentrum.hu/ letöltés ideje: 2018.03.13. 